\title{
Comparison of ultrasound and physical examination with computerized tomography in patients with blunt abdominal trauma
}

\author{
Azad Hekimoğlu, M.D., ${ }^{1} \odot$ Onur Ergun, M.D., ${ }^{1} \odot$ Seda Özkan, M.D., ${ }^{2}$ \\ Engin Deniz Arslan, M.D., ${ }^{2}$ Baki Hekimoğlu, M.D. ${ }^{1}$
}

1Department of Radiology, Dışkapı Yıldırım Beyazıt Training and Research Hospital, Ankara-Turkey
${ }^{2}$ Department of Emergency Medicine, Dışkapı Yıldırım Beyazıt Training and Research Hospital, Ankara-Turkey

\begin{abstract}
BACKGROUND: In cases of blunt abdominal trauma, the abdomen is the third most affected region. Computerized tomography (CT) is the gold standard for the evaluation of these patients. However, considering its damaging effects and high cost, it may not be proper to refer every patient applying to the emergency unit for a CT examination. In this study, our objective was to compare the accuracy of ultrasonography (US) and physical examination in blunt abdominal trauma patients to the gold standard CT in order to prevent unnecessary CT examinations.
\end{abstract}

METHODS: In this retrospective study, the files and images of 2248 patients, who applied to the emergency department of our hospital were screened. A total of 535 adult patients who underwent CT scanning after the ultrasonographic and physical examinations were included in the study. The findings of the US and physical examinations, the intraabdominal free fluid, and organ lacerations were compared to the results of CT. The compatibility, sensitivity, specificity, positive estimated value, and the negative estimated value of the obtained data were analyzed with statistical methods.

RESULTS: The sensitivity of US in the demonstration of the intraabdominal free fluid was comparable with the sensitivity of CT in the patients with blunt abdominal trauma $(\mathrm{p}=0.302)$. The sensitivity and specificity of US was $49.6 \%$ and $99.3 \%$ respectively in the determination of the intraabdominal organ injuries. The sensitivity and specificity of the physical examination was $59 \%$ and $87 \%$ respectively in the determination of the free fluid and organ injury as compared to CT. Although the sensitivity and specificity of the physical examination were high separately in the organ injuries according to the statistical calculations, they seemed not to have had a statistically significant predictive value $(p<0.001)$.

CONCLUSION: Even though US is a reliable method for the determination of the intraabdominal fluid, US and physical examination are not reliable in the determination of the organ injuries as compared to $\mathrm{CT}$.

Keywords: Abdomen; physical examination; tomography; trauma; ultrasonography.

\section{INTRODUCTION}

Trauma is currently the fourth most common cause of mortality in developed countries ${ }^{[1]}$ and is the most common cause of mortality in the first four decades of life. ${ }^{[2]}$ Fifty percent of the deaths below the age of 14 years, $80 \%$ of the deaths between 15 and 25 years of age and $65 \%$ of the deaths between
25 and 40 years of age are caused by trauma. ${ }^{[3]}$ Abdominal traumas are the third most common cause of trauma-related deaths. ${ }^{[4]}$ Traditionally, abdominal traumas are classified into two groups, penetrating and blunt abdominal traumas. In most cases, penetrating traumas can be easily diagnosed but blunt traumas are usually overlooked since the clinical findings are less prominent. ${ }^{[5]}$ Death due to abdominal trauma

Cite this article as: Hekimoğlu A, Ergun O, Özkan S, Arslan ED, Hekimoğlu B. Comparison of ultrasound and physical examination with computerized tomography in patients with blunt abdominal trauma. Ulus Travma Acil Cerrahi Derg 2019;25:369-377.

Address for correspondence: Azad Hekimoğlu, M.D.

Dışkapı Yıldırım Beyazıt Eğitim ve Araştırma Hastanesi, Radyoloji Kliniği, 06100 Ankara, Turkey

Tel: +90 312 - 5962618 E-mail: azadhekimoglu@gmail.com 
may be prevented if timely diagnosed. ${ }^{[6]}$ Isolated blunt abdominal trauma constitutes $5 \%$ of the mortality due to the trauma and the blunt abdominal trauma contributes to $15 \%$ of the mortality due to the trauma in polytraumatic injuries. ${ }^{[7]}$

Regarding the diagnosis, classification, and approach to the trauma patient, computerized tomography $(C T)$ is very useful.

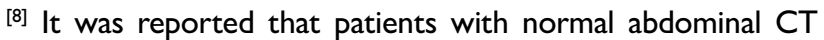
imaging do not need additional treatment. ${ }^{[9]}$ In short, CT is the gold standard for the evaluation of the abdominal traumas. ${ }^{[10-14]}$ The sensitivity increases to approximately $100 \%$ in the repeated CT scans while the specificity also increases to $86 \%$. ${ }^{[15]}$ However, considering its damaging effects and high cost, it may not be proper to refer every patient applying to the emergency unit for a CT examination. In this study, our objective was to compare the accuracy of ultrasonography (US) and physical examination in blunt abdominal trauma patients to the gold standard CT in order to prevent unnecessary CT examinations.

\section{MATERIALS AND METHODS}

In this retrospective study, the files and images of 2248 patients, who applied to the emergency department of our hospital between January 2015 and March 2017 were screened. A total of 535 adult abdominal trauma patients ( 359 males, 176 females) who underwent CT examination after the ultrasonographic and physical examination were included in the study. Patients with penetrating abdominal injuries, intraabdominal ascites, patients whose files could not be accessed, those who were unconscious, those who did not undergo a physical examination, and those who were younger than 16 years were not included in the study. The age of the participants was between 16 years and 87 years (average: 37.5 years). Out of the total sample size, $162(30.3 \%)$ patients had an extravehicular traffic accident, $23(4.3 \%)$ had a motorcycle accident, 6 (I.1\%) fell from a tractor, 304 (56.8\%) had an intravehicular traffic accident, and 40 (7.5\%) fell from a height (Table I). ISS (injury severity score) and NISS (new injury severity score) scores of all patients were calculated. The mean ISS and NISS values of the patients were $8(I-57)$ and 133 (24.9\%). A total of 167 (3I.2\%) patients had an ISS and NISS score above 16 respectively.

\section{Physical Examination}

The physical examination of patients who had applied to the emergency room with blunt abdominal trauma was carried out by our experienced physicians in the emergency department of Dışkapı Yıldırım Beyazıt Training and Research Hospital, which is also the main trauma center of our city. Unconscious and agitated patients who had refused to be examined due to severe pain were excluded from the study.

As inspection, auscultation, and percussion would not be meaningful in the abdominal examination of these patients, the physical examination was limited to palpation. For the
Table I. Demographic and clinical characteristics of the patients

\begin{tabular}{|c|c|}
\hline & $n=535$ \\
\hline Age (year), mean $\pm S D$ & $37.5 \pm 18.0$ \\
\hline Age interval (years) & $16-87$ \\
\hline \multicolumn{2}{|l|}{ Gender, n (\%) } \\
\hline Male & $359(67.1)$ \\
\hline Female & $176(32.9)$ \\
\hline \multicolumn{2}{|l|}{ Etiology, n (\%) } \\
\hline Intravehicular traffic accident & $304(56.8)$ \\
\hline Extravehicular traffic accident & $162(30.3)$ \\
\hline Motorcycle accident & $23(4.3)$ \\
\hline Fall from tractor & $6(1.1)$ \\
\hline Fall from height & $40(7.5)$ \\
\hline Pelvis fractures, n (\%) & $89(16.6)$ \\
\hline Pubic ramus & $56(62.9)$ \\
\hline \multicolumn{2}{|l|}{ Physical examination, n (\%) } \\
\hline Tenderness 0 & $382(71.4)$ \\
\hline Tenderness I & $129(24.1)$ \\
\hline Tenderness 2 & $24(4.5)$ \\
\hline ISS & $8(1-57)$ \\
\hline ISS > I6, n (\%) & $133(24.9)$ \\
\hline NISS & $8(I-57)$ \\
\hline NISS > 16, n (\%) & $167(31.2)$ \\
\hline \multicolumn{2}{|l|}{ Clinical progress, n (\%) } \\
\hline Nephrectomy & $3(0.6)$ \\
\hline Splenectomy & $26(4.9)$ \\
\hline Deaths & $30(5.6)$ \\
\hline
\end{tabular}

ISS: Injury severity score; NISS: New injury severity score; SD: Standard deviation.

convenience of the evaluation, palpation was categorized into three groups.

- Tenderness 0: Absence of or minimal abdominal tenderness during the abdominal palpation.

- Tenderness I: Presence of prominent tenderness during the abdominal palpation.

- Tenderness 2: Presence of defense or rebound during the abdominal palpation.

\section{Imaging}

CT and US examinations were carried out in our radiology department by radiologists with at least 5 years of experience. US examination was performed in the supine position with the convex probe of the US device Esolute Mylab 60 and the abdomen of the patients was investigated. During the examination, all quadrants of the abdomen from the xiphoid to pelvis were thoroughly evaluated. As per standard US procedure, the presence of the intraabdominal free fluid was ex- 
amined first, after which the presence of intraabdominal solid organ lacerations was determined.

After the US examination, the abdomen of the patients was scanned from diaphragm to pelvis with Toshiba Alexion 16 slice CT Scanner. lohexol $300 \mathrm{mg} \mathrm{I/mL}$ was administered intravenously according to the weight of the patient with an Imaxeon syringe. All captured images were recorded in the hospital's PACS System.

\section{Statistical Analysis}

Descriptive discrete numeric variables were shown with mean \pm standard deviation or median (minimum-maximum). Categorical variables were expressed as numbers of observations and percentage.

The McNemar test was used to investigate whether the US and physical examinations had significant predictive value as compared to the gold standard CT with respect to identifying the cases. For every CT finding, sensitivity, specificity, positive estimated value, negative estimated value, and diagnostic accuracy rate related to the US and physical examination were calculated.

The statistical compatibility of the findings of the US and physical examinations with the CT findings were evaluated by calculating the Kappa coefficient. A Kappa coefficient smaller than 0 was considered as the absence of compatibility; $0.0-0.20$ indicated clinically insignificant compatibility; $0.21-0.40$ indicated moderate compatibility; $0.4 \mathrm{I}-0.60$ indicated the compatibility for the majority; $0.61-0.80$ indicated significant compatibility; and $0.8 \mathrm{I}-\mathrm{I} .00$ indicated almost perfect compatibility. ${ }^{[16]}$

The data analyses were done with IBM SPSS Statistics 17.0 (IBM Corporation, Armonk, NY, USA) package software. A $\mathrm{P}$-value of $<0.05$ was considered statistically significant.

\section{RESULTS}

A total of 30 patients (5.6\%) with high ISS and NISS scores died due to the extra-abdominal causes. In 367 of the participating 535 patients (68.6\%), no pathological finding including the minimal fluid was determined. In 65 (38\%) of the 168 patients with intraabdominal fluid (31.4\%) minimal fluid was the only observed finding and these patients were discharged after a short hospitalization period. A total of 12 patients (2.2\%) with organ injuries ( 7 patients with grade I liver injury, I patient with grade I spleen injury, 2 patients with minimal kidney injury, and I patient with intestinal injury) did not have intraabdominal free fluid except for the minimal fluid at the injury site. A total of 115 patients $(21 \%)$ had organ injury and 12 of them (10.4\%) had multiple organ injuries (Table 2).

While no fluid was observed in 340 patients $(63.6 \%)$ during the US and physical examination, 149 patients $(27.9 \%)$
Table 2. Twelve patients with multiple organ trauma

\begin{tabular}{lcccc}
\hline & Liver & Spleen & Kidney & Intestines \\
\hline I patient & + & + & + & + \\
3 patients & + & + & + & \\
3 patients & + & + & & \\
4 patients & & + & + & + \\
I patient & + & & & + \\
\hline
\end{tabular}

Table 3. Clinical findings with respect to the gold standard CT and alternative imaging method, US

\begin{tabular}{|c|c|c|}
\hline & \multicolumn{2}{|c|}{ CT - fluid } \\
\hline & None & Present \\
\hline \multicolumn{3}{|l|}{ US - fluid } \\
\hline None & 340 (63.6\%) & $19(3.5 \%)$ \\
\hline \multirow[t]{3}{*}{ Present } & $27(5.0 \%)$ & 149 (27.9\%) \\
\hline & \multicolumn{2}{|c|}{ CT - liver } \\
\hline & No laceration & Laceration \\
\hline \multicolumn{3}{|l|}{ US - liver } \\
\hline No laceration & 490 (91.6\%) & 18 (3.4\%) \\
\hline \multirow[t]{3}{*}{ Laceration } & $2(0.4 \%)$ & 25 (4.6\%) \\
\hline & \multicolumn{2}{|c|}{ CT - spleen } \\
\hline & No laceration & Laceration \\
\hline \multicolumn{3}{|l|}{ US - spleen } \\
\hline No laceration & $47 \mathrm{I}(88.0 \%)$ & 30 (5.6\%) \\
\hline \multirow[t]{3}{*}{ Laceration } & $3(0.6 \%)$ & 31 (5.8\%) \\
\hline & \multicolumn{2}{|c|}{ CT - kidney } \\
\hline & No laceration & Laceration \\
\hline \multicolumn{3}{|l|}{ US - kidney } \\
\hline No laceration & $516(96.4 \%)$ & $14(2.7 \%)$ \\
\hline Laceration & $0(0.0 \%)$ & $5(0.9 \%)$ \\
\hline
\end{tabular}

CT: Computerized tomography; US: Ultrasonography.

showed the presence of fluid in both US and CT examinations. The US findings were compatible with the CT findings regarding the identification of the patients with and without intraabdominal fluid (Kappa=0.808). In other words, the detection rate of the fluid was statistically comparable between the CT and US examinations $(p=0.302)$ (Tables 3 and 4).

Although the findings of US and CT were comparable regarding the detection of the hepatic, splenic and renal lacerations (Kappa: $0.695,0.622$, and 0.408 respectively), these lacera- 
Table 4. Diagnostic performance indicators of the US as compared to the gold standard CT

\begin{tabular}{|c|c|c|c|c|}
\hline & Sensitivity (\%) & Selectivity (\%) & Positive estimated value (\%) & Negative estimated value (\%) \\
\hline \multicolumn{5}{|l|}{ Ultrasonography } \\
\hline Fluid presence & 88.7 & 92.6 & 84.7 & 94.7 \\
\hline Liver laceration & 58.1 & 99.6 & 92.6 & 96.5 \\
\hline Spleen laceration & 50.8 & 99.4 & 91.2 & 94.0 \\
\hline Kidney laceration & 26.3 & 100.0 & 100.0 & 97.4 \\
\hline
\end{tabular}

Table 5. Clinical findings of the patients with the organ injury with respect to the gold standard CT and alternative imaging method, US

\begin{tabular}{lcccc}
\hline & \multicolumn{3}{c}{ CT - organ injury } & p $^{\dagger}$ \\
\cline { 2 - 4 } & None & Present & Total & $<0.001$ \\
\hline Ultrasonography - organ injury, $\mathrm{n}(\%)$ & & & $\left.059\right|^{\ddagger}$ \\
$\quad$ None & $417(77.9)$ & $58(10.8)$ & $475(88.7)$ & \\
Present & $3(0.6)$ & $57(10.7)$ & $60(11.3)$ \\
Total & $420(78.5)$ & $115(21.5)$ & $535(100.0)$ \\
\hline
\end{tabular}

Data; were expressed as the number of observations and percentage, ${ }^{\dagger}$ McNemar test, ${ }^{\dagger}$ Kappa coefficient was found as statistically significant $(p<0.00 \mathrm{I})$.

Table 6. Frequency distributions of physical examination findings according to the gold standard CT

\begin{tabular}{lccc}
\hline & In CT no fluid & In CT only fluid was observed & In CT organ injury \\
\hline Tenderness 0 & 309 & 50 & 23 \\
$\quad$ Number of patients & 80.9 & 13.1 & 6.0 \\
According to physical examination (\%) & 87.0 & 76.9 & 20.0 \\
According to CT (\%) & & 15 & 68 \\
Tenderness I & 46 & 11.6 & 52.7 \\
Number of patients & 35.7 & 23.1 & 59.1 \\
According to physical examination (\%) & 13.0 & & 24 \\
According to CT (\%) & & 0 & 100.0 \\
Tenderness 2 & 0 & 0.0 & 20.9 \\
Number of patients & 0.0 & 0.0 & \\
According to physical examination (\%) & 0.0 & & \\
According to CT (\%) & & & \\
\hline
\end{tabular}

CT: Computerized tomography.

tions were significantly clearer with $\mathrm{CT}$ as compared to US $(p<0.00 I)$. In other words, it was found out that the rate of false negative results with US was significantly higher in the detection of the hepatic, splenic, and renal lacerations (Table $3,4)$.

With respect to the detection of at least one organ injury, findings of CT and US were comparable (Kappa=0.59l), but the detection rate of organ injury with $\mathrm{CT}$ was significantly higher than US $(p<0.001)$ (Table 5$)$. CT is the gold standard for the detection of at least one organ injury. In compar- ison to CT, the sensitivity, specificity, positive estimated value, negative estimated value, and accuracy rate of US were $49.6 \%, 99.3 \%, 95.0 \%, 87.8 \%$, and $88.6 \%$ respectively.

According to the results of the physical examination (palpation), 382 patients (7I.4\%) had tenderness 0, 129 (24.1\%) had tenderness I, and 24 (4.5\%) had tenderness 2 (Table 6).

In 309 of the 355 patients (87.0\%) who presented with organ injury without fluid in $\mathrm{CT}$, no tenderness was observed during the physical examination. On the other hand, 50 of 
Table 7. Clinical findings of the patients according to the physical examination as compared to the gold standard CT

\begin{tabular}{|c|c|c|c|c|}
\hline & \multicolumn{3}{|c|}{ CT - liver } & \multirow[t]{2}{*}{$\mathbf{p}^{\dagger}$} \\
\hline & No laceration & Laceration & Total & \\
\hline Physical examination, n (\%) & & & & $<0.001$ \\
\hline Tenderness 0 & $375(70.1)$ & $7(1.3)$ & $382(71.4)$ & \\
\hline Tenderness I+2 & 117 (21.9) & $36(6.7)$ & $153(28.6)$ & \\
\hline \multirow[t]{3}{*}{ Total } & $492(92.0)$ & $43(8.0)$ & $535(100.0)$ & \\
\hline & \multicolumn{3}{|c|}{ CT - spleen } & $\mathbf{p}^{\dagger}$ \\
\hline & No laceration & Laceration & Total & \\
\hline Physical examination, n (\%) & & & & $<0.001$ \\
\hline Tenderness 0 & $370(69.2)$ & $12(2.2)$ & $382(71.4)$ & \\
\hline Tenderness I+2 & $104(19.4)$ & $49(9.2)$ & $153(28.6)$ & \\
\hline \multirow[t]{3}{*}{ Total } & $474(88.6)$ & $61(11.4)$ & $535(100.0)$ & \\
\hline & \multicolumn{3}{|c|}{ CT - kidney } & $\mathbf{p}^{\dagger}$ \\
\hline & No laceration & Laceration & Total & \\
\hline Physical examination, n (\%) & & & & $<0.001$ \\
\hline Tenderness 0 & $378(70.6)$ & $4(0.8)$ & $382(71.4)$ & \\
\hline Tenderness I+2 & I38 (25.8) & $15(2.8)$ & $153(28.6)$ & \\
\hline Total & $516(96.4)$ & $19(3.6)$ & $535(100.0)$ & \\
\hline
\end{tabular}

Data; were expressed as the number of observations and percentage, ${ }^{\dagger} \mathrm{McNemar}$ test.

the 65 patients $(76.9 \%)$ who had fluid without concomitant organ injury also had no tenderness during the physical examination. Only 23 of the II 5 patients $(20.0 \%)$ who had at least one organ injury in CT had no tenderness during the physical examination. Nevertheless, 68 of the II5 patients (59.1\%) who had at least one organ injury in CT, had tenderness I during the physical examination and 24 (20.9\%) had tenderness 2 (Table 6). Herewith, the sensitivity, specificity, positive estimated value, and negative estimated value were $59 \%, 87 \%, 70 \%$, and $81 \%$ respectively as compared to the gold standard CT.

The patients who either had no fluid in CT or solely had fluid in CT showed no defense or rebound during the physical examination. Only 24 (20.9\%) of the II5 patients who had at least one organ injury in CT showed a defense or rebound during the physical examination. In other words, in all 24 patients who had a defense or rebound during the physical examination, at least one organ injury was detected with CT. To summarize, the rate of absence of tenderness during the physical examination decreased proportionally from the group without fluid in CT examination toward the group with at least one organ injury in CT examination. In comparison with the groups who had no fluid in CT or solely had fluid in $\mathrm{CT}$, the group who had at least one organ injury in $\mathrm{CT}$ showed increased tenderness to physical examination, how- ever, defense or rebound percentages showed a more significant increase.

Separate statistical calculation of the physical examination findings for the organ injuries showed that the physical examination did not have a significant statistical predictive value in spite of its high sensitivity and specificity with respect to the identification of hepatic $(83.7 \%, 76.2 \%)$, splenic $(80.3 \%$, 78.1\%), and renal lacerations (78.9\%, 73.3\%) $(p<0.001)$ (Table $7)$. On the other hand, 6 of the 9 patients with intestinal injury had tenderness 2 during the physical examination and 3 had tenderness $\mathrm{I}$. This showed that all patients with intestinal injury had a positive physical examination.

\section{DISCUSSION}

It was clearly demonstrated that CT is a perfect imaging method for the evaluation of patients with blunt abdominal trauma. The early diagnosis enabled by CT contributes to the significant reduction of the morbidity and mortality related to traumatic abdominal injuries. ${ }^{\left[{ }^{\prime \prime}\right]}$ However, the common usage of the $\mathrm{CT}$ in recent years causes certain problems due to radiation exposure and its adverse effects, including the risk of future malignancies. ${ }^{[17]}$ In our study, 367 (68.6\%) of 535 patients who underwent CT examination had no pathological findings, including minimal fluid. Also, 65 (38\%) of 168 
patients with intraabdominal fluid (31.4\%) had minimal fluid and were discharged after a short hospitalization period. Only I I 5 patients of the participating 535 patients (2I\%) had a prominent pathological finding. We also took into consideration the patients who had only minimal fluid and were discharged without observation of any pathological finding, on the basis of which we suggested that CT examination was unnecessary in $79 \%$ of the patients.

US examination was introduced into the investigation of the blunt abdominal trauma in the 1970s. ${ }^{[18]}$ US examination usually is carried out with focused assessment with sonography in trauma (FAST) in trauma patients. This examination method enables a fast and general view into the intraperitoneal space to determine the presence of acute bleeding and free fluid, which is an indirect sign of visceral organ injury. ${ }^{[19-21]}$ According to the literature, US sensitivity was between $63 \%$ and $99 \%$ when evaluating the intraperitoneal fluid. ${ }^{[22,23]}$ Meta-analyses showed that the sensitivity and specificity of the US examination were $80 \%$ and $96 \%$ respectively in pediatric trauma patients. ${ }^{[1]}$ However, its sensitivity is significantly lower in the diagnosis of parenchymal injuries. ${ }^{[0]}$ Furthermore, it has certain disadvantages such as a limitation in showing intestinal perforations and insufficient reliability in patients with intraabdominal ascites and obesity. In our study, the sensitivity, specificity, and accuracy of the US in comparison to the CT were $88.7 \%, 92.6 \%$, and $91.5 \%$ respectively when showing the intraabdominal free fluid in patients with blunt abdominal trauma. The detection rate of the fluid was statistically comparable with CT $(p=0.302)$. In their study, Kimura and Otsuka showed that US was a reliable method for the detection of the hemoperitoneum after blunt abdominal trauma. ${ }^{[2]}$ They reported sensitivity, specificity, and accuracy rates $(86.7 \%$, $100 \%$, and $97.2 \%$ respectively) that were very close to the results of our study.

In their study, Katz and his colleagues reported that US was a sensitive and effective method to determine the presence of peritoneal free fluid and visceral organ injuries. The reported percentages of sensitivity, specificity, and accuracy were $90.9 \%, 83.6 \%$, and $84.3 \%$ respectively. ${ }^{[25]}$ However, the general statement in most of the studies in the literature was that the sensitivity of US was low in the detection of the organ injuries. ${ }^{[26,27]}$ In our study, the evaluation of the organ injuries showed that the detection rate of the organ injuries with CT was significantly higher as compared to US $(p<0.00 \mathrm{I})$. We found out that the sensitivity and specificity of US in detecting the organ injuries were $49.6 \%$ and $99.3 \%$ respectively.

In blunt abdominal trauma, the spleen is the most commonly injured organ and constitutes $25 \%-30 \%$ of the total intraabdominal injuries. The typical findings in the patients with large traumas were subcapsular hematoma and laceration of the splenic tissue. ${ }^{[28]}$ As spleen injuries are a significant part of intraabdominal traumas, early diagnosis is critical to limit morbidity and mortality. ${ }^{[29]}$ The high blood perfusion of the spleen may cause fatal outcomes if its injuries are not timely taken into consideration. ${ }^{[30]}$ In blunt abdominal traumas, the primary goal of the US examination of the spleen is to determine the presence of the blood in the left upper quadrant. [31] Except for the cases with no deterioration of the capsule integrity, hemoperitoneum in the left upper quadrant almost always indicates a splenic injury. ${ }^{[32]}$ It was shown that US sensitivity was $\mathbf{7 2 . 4 \%}$ in major splenic injuries and $57.8 \%$ in minor splenic injuries. ${ }^{[33]}$ Richards and his colleagues found that the US sensitivity was $78 \%$ in Grade III and higher spleen injuries and stated that this level of sensitivity was insufficient for the spleen injuries with lower grades. ${ }^{[34]}$ In our study, 61 patients (II.4\%) had a splenic injury and 26 of them (42.6\%) underwent splenectomy. Spleen laceration was detected in $34(6.4 \%)$ patients with US and its sensitivity and specificity were calculated as $50.8 \%$ and $99.4 \%$ respectively. The detection rate of the spleen lacerations with CT was significantly higher than US $(p<0.00 I)$. In other words, the rate of false negative results with US was significantly higher in the determination of spleen lacerations.

In spite of the anatomical protection of the liver, it is the second most commonly injured organ in the blunt traumas. ${ }^{[35]}$ It was reported that the rate of liver injuries in patients with blunt abdominal trauma was between $1 \%$ and $8 \% .^{[36]}$ Most liver injuries occur in the posterior segment of the right lobe. ${ }^{[37]}$ The major findings of the blunt abdominal trauma detected with CT are lacerations, subcapsular and parenchymal hematomas, active hemorrhage, and juxtahepatic venous injuries. Periportal low attenuation and flat inferior vena cava may be mentioned among minor CT findings. Bile leakage is common in hepatic lacerations, however, it is limited and transient in most of the cases and sequelae are not usually observed. Serious injuries that require treatment for intrahepatic or extrahepatic bile canals are relatively rare. ${ }^{[38]}$ In their study, Marco et al. ${ }^{[33]}$ found that in major liver injuries, sensitivity and specificity of US were $75 \%$ and $99.1 \%$ respectively and in minor liver injuries, they were $62.5 \%$ and $99.1 \%$ respectively. In our study, we detected liver laceration in 43 patients (8\%) and only 4 of them $(9.3 \%)$ underwent surgical intervention. US revealed laceration in 27 patients (5\%) and the sensitivity and specificity were $58.1 \%$ and $99.6 \%$ respectively. The detection rate of liver lacerations with CT was significantly higher than US $(p<0.001)$. In other words, the rate of false negative results was significantly higher in US regarding the detection of the liver lacerations.

Although kidneys are the most commonly injured urogenital organs, their injury rate is lower than that of the spleen and liver. The risk of renal injury due to blunt trauma is higher in the pediatric population as compared to the adult population. ${ }^{[39]}$ A pre-existing renal anomaly increases the risk of injury and kidney traumas are more common among children as compared to adults in the presence of kidney anomalies. Such injuries include the disruption of the renal pelvis or the 
ureteropelvic junction in patients with hydronephrosis, intracystic hemorrhage or renal cyst rupture, laceration of the ectopic or horseshoe kidney, and laceration of the infected kidneys. ${ }^{[40]}$ Further, in their study, Marco et al. ${ }^{[33]}$ reported the sensitivity and specificity in major kidney injuries as $30.7 \%$ and $97.6 \%$ respectively and in minor kidney injuries as $54.5 \%$ and $99.3 \%$ respectively. In our study, we detected kidney laceration in 19 patients (3.6\%) and 3 of them (15.8\%) underwent nephrectomy. Lacerations were detected in 5 patients $(0.9 \%)$ with the US examination and consequently, the calculated sensitivity and specificity were $26.3 \%$ and $100 \%$ respectively. The detection rate of renal lacerations with $\mathrm{CT}$ was significantly higher than US $(p<0.00 \mathrm{I})$. In other words, the rate of false negative results with US is significantly high regarding the kidney lacerations.

Intestinal and mesenteric injuries were encountered in $5 \%$ of the blunt traumas. As the mortality rate due to these type of injuries is high, early diagnosis is critical. ${ }^{[4]}$ The detection of intestinal injuries with US is extremely difficult. The characteristic findings include thickening of the intestinal wall, pneumoperitoneum, and presence of focal fluid. ${ }^{[42]}$ Richard and his colleagues reported that $49 \%$ of the patients with intestinal and mesenteric injuries also present with injuries in other organs. It was reported that the sensitivity of US for the detection of the free fluid was $44 \%$ in isolated intestinal and mesenteric injuries. ${ }^{[43]}$ In their study, Abu-Zidan et al. ${ }^{[44]}$ were not able to detect any of the 3 intestinal injuries with US and thus they reported the sensitivity of US as $0 \%$. In our study, we observed intestinal perforation in 9 patients (I.7\%) and it was concomitant with spleen, liver, and right kidney lacerations in I patient and with the liver laceration in another patient. We detected isolated intestinal injury in only 7 patients. US examination revealed prominent fluid in all patients except $\mathrm{I}$, in whom we could not even detect fluid with US and loculated fluid was observed around the colon in the CT examination. As only fluid was observed and no other prominent pathological finding was detected in the intestinal and mesenteric injuries with US, we also considered the sensitivity of US as $0 \%$.

In our study, US did not directly show any of the intestinal or mesenteric injuries and in our opinion, it might be also incapable of detecting injuries of the diaphragm, pancreas, adrenal gland, and bone. Its usefulness is probably also limited in several vascular injuries. ${ }^{[27]}$ As a result, US is not a reliable method in the determination of injuries except in assessing the free fluid in the blunt abdominal traumas. Moreover, we noticed that the reliability of the US examination is more decreased if 12 patients (2.2\%) who had minimal organ injury without prominent free fluid were taken into consideration.

A physical examination is traditionally an important tool in assessing the general condition of the patient. Soyuncu et al..$^{[45]}$ compared the reliability of the physical examination with the US examination and reported that the physical examination had a sensitivity of $39 \%$ and a specificity of $90 \%$ in the determination of the intraabdominal hemorrhage. Another study demonstrated that physical examination caused false results in one-third of the patients with blunt abdominal trauma. ${ }^{[46]}$ In such studies, the investigators especially emphasized that patients who had clouding of consciousness due to cranial trauma or extra-abdominal trauma did not show an optimal response to the physical examination. However, in another study conducted by Ferrera and colleagues, the sensitivity and specificity of the physical examination were $82 \%$ and $45 \%$ respectively in blunt abdominal traumas. ${ }^{[4]}$ In our study, an overall calculation of the sensitivity, specificity, positive estimated value, and negative estimated value of the physical examination for all patients displayed rates of $59 \%, 87 \%, 70 \%$, and $81 \%$ respectively. Furthermore, Ferrera and colleagues reported that they detected intraabdominal injuries in $7 \%$ of the patients with normal physical examination. ${ }^{[4]}$ In our study, $87 \%$ of the patients with no pathological finding on CT also had a normal physical examination. However, $59.1 \%$ of the patients had tenderness I and $20.9 \%$ had tenderness 2 , so the rate of positive findings in the physical examination was $80 \%$.

Separate statistical calculations for patients with liver, spleen, and kidney lacerations were performed and the sensitivity and specificity of the physical examination were $83.7 \%$ and $76.2 \%$ respectively for the liver, $80.3 \%$ and $78.1 \%$ respectively for the spleen, and $78.9 \%$ and $73.3 \%$ for the kidney, which was statistically not comparable with $C T(p<0.00 I)$. On the other hand, all 9 patients with intestinal injury also had positive symptoms during the physical examination.

The most important finding of our study was that the patients with tenderness score 2 (the presence of defense and rebound during the palpation) had at least one organ injury. Eventually, the rate of the tenderness during the physical examination increased proportionally from the group without any pathological finding in CT examination toward the group with at least one organ injury in CT examination. Nevertheless, we were not able to achieve the exact desired results in the other two groups except the group with defense and rebound.

Finally, we observed pelvic fractures in 89 patients (16.6\%). In 56 of them, the fracture was located in the pubic ramus. The most common extra-abdominal injury is the pelvic fracture in trauma patients, especially fractures of the pubic ramus. The mortality rate in patients with untreated pelvic fractures is between $4 \%$ and $15 \%{ }^{[48]}$

\section{Conclusion}

We found an abundant number of unnecessary CT examinations, especially with respect to discharged patients with minimal fluid and no other pathologies during follow up. Although the reliability of US in the determination of the intraabdominal fluid is well established, its reliability in the 
detection of organ injuries is rather limited. The findings also indicated that physical examination is not a reliable tool for diagnosis in traumatic patients. Therefore, CT is currently the best method for the early diagnosis of patients with traumatic organ injury if used with the correct indication.

\section{Conflict of interest: None declared.}

\section{REFERENCES}

1. Holmes JF, Gladman A, Chang CH. Performance of abdominal ultrasonography in pediatric blunt trauma patients: a meta-analysis. J Pediatr Surg 2007;42:1588-94. [CrossRef]

2. Natarajan B, Gupta PK, Cemaj S, Sorensen M, Hatzoudis GI, Forse RA. FAST scan: is it worth doing in hemodynamically stable blunt trauma patients? Surgery 2010;148:695-700. [CrossRef]

3. Ertekin C. Multipl travmalı hastaya yaklaşım. Yoğun Bakım Dergisi 2002;2:77-87.

4. Shojaee M, Faridaalaee G, Yousefifard M, Yaseri M, Arhami Dolatabadi A, Sabzghabaei A, et al. New scoring system for intra-abdominal injury diagnosis after blunt trauma. Chin J Traumatol 2014;17:19-24.

5. Aldemir M, Taçyildiz I, Girgin S. Predicting factors for mortality in the penetrating abdominal trauma. Acta Chir Belg 2004;104:429-34. [CrossRef]

6. Farrath S, Parreira JG, Perlingeiro JAG, Soldá SC, Assef JC. Fatores preditivos de lesões abdominais em vítimas de trauma fechado.[Article in Spanish] Rev Col Bras Cir 2012;39:295-300. [CrossRef]

7. Anderson RN, Miniño AM, Fingerhut LA, Warner M, Heinen MA. Deaths: injuries, 2001. Natl Vital Stat Rep 2004;52:1-86. [CrossRef]

8. Mullinix AJ, Foley WD. Multidetector computed tomography and blunt thoracoabdominal trauma. J Comput Assist Tomogr 2004;28:S20-7.

9. Holmes JF, McGahan JP, Wisner DH. Rate of intra-abdominal injury after a normal abdominal computed tomographic scan in adults with blunt trauma. Am J Emerg Med 2012;30:574-9. [CrossRef]

10. Thorelius L. Emergency real-time contrast-enhanced ultrasonography for detection of solid organ injuries. Eur Radiol 2007;17:107-11. [CrossRef]

11. Novelline RA, Rhea JT, Rao PM, Stuk JL. Helical CT in emergency radiology. Radiology 1999;213:321-39. [CrossRef]

12. Shuman WP. CT of blunt abdominal trauma in adults. Radiology 1997;205:297-306. [CrossRef]

13. Lynch T, Kilgar J, Al Shibli A. Pediatric Abdominal Trauma. Curr Pediatr Rev 2018;14:59-63. [CrossRef]

14. Wortman JR, Uyeda JW, Fulwadhva UP, Sodickson AD. Dual-Energy CT for Abdominal and Pelvic Trauma. Radiographics 2018;38:586-602.

15. Brooke M, Victorino GP. Repeat computed tomography is highly sensitive in determining need for delayed exploration in blunt abdominal trauma. J Surg Res 2017;219:116-21. [CrossRef]

16. Landis JR, Koch GG. The measurement of observer agreement for categorical data. Biometrics 1977;33:159-74. [CrossRef]

17. Brenner DJ, Hall EJ. Computed tomography--an increasing source of radiation exposure. N Engl J Med 2007;357:2277-84. [CrossRef]

18. Kristensen JK, Buemann B, Kühl E. Ultrasonic scanning in the diagnosis of splenic haematomas. Acta Chir Scand 1971;137:653-7.

19. Kirkpatrick AW, Sirois M, Laupland KB, Goldstein L, Brown DR, Simons RK, et al. Prospective evaluation of hand-held focused abdominal sonography for trauma (FAST) in blunt abdominal trauma. Can J Surg 2005;48:453-60.

20. Scalea TM, Rodriguez A, Chiu WC, Brenneman FD, Fallon WF Jr, Kato K, et al. Focused Assessment with Sonography for Trauma
(FAST): results from an international consensus conference. J Trauma 1999;46:466-72. [CrossRef]

21. Bloom BA, Gibbons RC. Focused Assessment with Sonography for Trauma (FAST). StatPearls [Internet]. Treasure Island (FL): StatPearls Publishing; 2018.

22. Cokkinos D, Antypa E, Stefanidis K, Tserotas P, Kostaras V, Parlamenti $A$, et al. Contrast-enhanced ultrasound for imaging blunt abdominal trauma - indications, description of the technique and imaging review. Ultraschall Med 2012;33:60-7. [CrossRef]

23. Valentino M, Serra C, Zironi G, De Luca C, Pavlica P, Barozzi L. Blunt abdominal trauma: emergency contrast-enhanced sonography for detection of solid organ injuries. AJR Am J Roentgenol 2006;186:1361-7.

24. Kimura A, Otsuka T. Emergency center ultrasonography in the evaluation of hemoperitoneum: a prospective study. J Trauma 1991;31:20-3.

25. Katz S, Lazar L, Rathaus V, Erez I. Can ultrasonography replace computed tomography in the initial assessment of children with blunt abdominal trauma? J Pediatr Surg 1996;31:649-51. [CrossRef]

26. Yoshii H, Sato M, Yamamoto S, Motegi M, Okusawa S, Kitano M, et al. Usefulness and limitations of ultrasonography in the initial evaluation of blunt abdominal trauma. J Trauma 1998;45:45-50. [CrossRef]

27. McGahan JP, Wang L, Richards JR. From the RSNA refresher courses: focused abdominal US for trauma. Radiographics 2001;21:191-9. [CrossRef]

28. Doody O, Lyburn D, Geoghegan T, Govender P, Munk PL, Torreggiani WC. Blunt trauma to the spleen: ultrasonographic findings. Clin Radiol 2005;60:968-76. [CrossRef]

29. Mirvis SE, Whitley NO, Gens DR. Blunt splenic trauma in adults: CTbased classification and correlation with prognosis and treatment. Radiology 1989;171:33-9. [CrossRef]

30. Hurd WW, Katholi RE. Acquired functional asplenia. Association with spontaneous rupture of the spleen and fatal spontaneous rupture of the liver in amyloidosis. Arch Intern Med 1980;140:844-5. [CrossRef]

31. Richards JR, McGahan PJ, Jewell MG, Fukushima LC, McGahan JP. Sonographic patterns of intraperitoneal hemorrhage associated with blunt splenic injury. J Ultrasound Med 2004;23:387-94. [CrossRef]

32. Rozycki GS, Ochsner MG, Feliciano DV, Thomas B, Boulanger BR, Davis FE, et al. Early detection of hemoperitoneum by ultrasound examination of the right upper quadrant: a multicenter study. J Trauma 1998;45:878-83. [CrossRef]

33. Marco GG, Diego S, Giulio A, Luca S. Screening US and CT for blunt abdominal trauma: a retrospective study. Eur J Radiol 2005;56:97-101.

34. Richards JR, McGahan JP, Jones CD, Zhan S, Gerscovich EO. Ultrasound detection of blunt splenic injury. Injury 2001;32:95-103. [CrossRef]

35. Cox EF. Blunt abdominal trauma. A 5-year analysis of 870 patients requiring celiotomy. Ann Surg 1984;199:467-74. [CrossRef]

36. Matthes G, Stengel D, Seifert J, Rademacher G, Mutze S, Ekkernkamp A. Blunt liver injuries in polytrauma: results from a cohort study with the regular use of whole-body helical computed tomography. World J Surg 2003;27:1124-30. [CrossRef]

37. Benya EC, Bulas DI, Eichelberger MR, Sivit CJ. Splenic injury from blunt abdominal trauma in children: follow-up evaluation with CT. Radiology 1995;195:685-8. [CrossRef]

38. Yoon W, Jeong YY, Kim JK, Seo JJ, Lim HS, Shin SS, et al. CT in blunt liver trauma. Radiographics 2005;25:87-104. [CrossRef]

39. Brown SL, Elder JS, Spirnak JP. Are pediatric patients more susceptible to major renal injury from blunt trauma? A comparative study. J Urol 1998;160:138-40. [CrossRef]

40. Kawashima A, Sandler CM, Corl FM, West OC, Tamm EP, Fishman EK, et al. Imaging of renal trauma: a comprehensive review. Radiographics 2001;21:557-74. [CrossRef] 
41. Rizzo MJ, Federle MP, Griffiths BG. Bowel and mesenteric injury following blunt abdominal trauma: evaluation with CT. Radiology 1989;173:143-8. [CrossRef]

42. Körner M, Krötz MM, Degenhart C, Pfeifer KJ, Reiser MF, Linsenmaier U. Current Role of Emergency US in Patients with Major Trauma. Radiographics 2008;28:225-42. [CrossRef]

43. Richards JR, McGahan JP, Simpson JL, Tabar P. Bowel and mesenteric injury: evaluation with emergency abdominal US. Radiology 1999;211:399-403. [CrossRef]

44. Abu-Zidan FM, Sheikh M, Jadallah F, Windsor JA. Blunt abdominal trauma: comparison of ultrasonography and computed tomography in a district general hospital. Australas Radiol 1999;43:440-3. [CrossRef]
45. Soyuncu S, Cete Y, Bozan H, Kartal M, Akyol AJ. Accuracy of physical and ultrasonographic examinations by emergency physicians for the early diagnosis of intraabdominal haemorrhage in blunt abdominal trauma. Injury 2007;38:564-9. [CrossRef]

46. Perry Jf Jr. A Five-Year Survey of 152 Acute Abdominal Injuries. J Trauma 1965;5:53-61. [CrossRef]

47. Ferrera PC, Verdile VP, Bartfield JM, Snyder HS, Salluzzo RF. Injuries distracting from intraabdominal injuries after blunt trauma. Am J Emerg Med 1998;16:145-9. [CrossRef]

48. Vaidya R, Scott AN, Tonnos F, Hudson I, Martin AJ, Sethi A. Patients with pelvic fractures from blunt trauma. What is the cause of mortality and when? Am J Surg 2016;211:495-500. [CrossRef]

\section{ORIJINAL ÇALIŞMA - ÖZET}

\section{Künt karın travmalı hastalarda ultrasonografi ve fizik muayenenin bilgisayarlı tomografi ile karşılaştırılması}

\section{Dr. Azad Hekimoğlu, ${ }^{1}$ Dr. Onur Ergun, ${ }^{1}$ Dr. Seda Özkan, ${ }^{2}$ Dr. Engin Deniz Arslan, ${ }^{2}$ Dr. Baki Hekimoğlu ${ }^{1}$}

${ }^{1}$ Dışkapı Yıldırım Beyazıt Eğitim ve Araştırma Hastanesi, Radyoloji Kliniği, Ankara

${ }^{2}$ Dışkapı Yıldııım Beyazıt Eğitim ve Araştırma Hastanesi, Acil Tıp Kliniği, Ankara

AMAÇ: Künt travmalarda karın bölgesi üçüncü en sık etkilenen yerdir. Bu hastaların değerlendirilmesinde bilgisayarlı tomografi (BT) altın standarttır. BT'nin hastaya olan zararlı etkileri ve maliyet yönünden düşünüldüğü zaman her acil servise gelen hastaya çekilmesi uygun bir yaklaşım olmayabilir. Çalışmamızda künt batın travması ile acil servise gelen hastaların ultrasonografi (US) ve fizik muayene bulgularının altın standart olan BT ile karşılaştırılması yapılarak gereksiz BT çekimlerinin önüne geçilmesi amaçlandı.

GEREÇ VE YÖNTEM: Hastanemiz acil servisine batın travması ile gelen 2248 hastanın dosya ve görüntüleri geriye dönük olarak tarandı ve çalısmaya uygun olan ve acil servisteki fizik muayenesinin ardından US ve sonrasında BT çekilen 535 yetişkin hasta çalışmaya alındı. Karın içi serbest sıvı ve organ laserasyonlarının US ve fizik muayene bulguları BT sonuçları ile ayrı ayrı karşılaşıııldı. Elde edilen değerlerin uyumluluk, duyarlıık, özgüllük, pozitif ve negatif tahmini değerleri istatistiksel olarak hesaplandı.

BULGULAR: Künt batın travmalı hastalarda US'nin karın içi serbest sıvıyı gösterme duyarlılı̆ı BT ile istatistiksel olarak benzerdi $(p=0.302)$. Karın içi organ yaralanmalarının saptanmasında ise US'nin duyarlıı̆ı \%49.6, özgüllüğü \%99.3 olarak bulundu. Fizik muayenenin ise BT'ye göre serbest sIVı ve organ yaralanmasının saptanmasında genel duyarlıı̆ı \%59, özgüllüğü \%87 olarak hesaplandı. Organ yaralanmaları için ayrı ayrı istatistiksel olarak hesaplandığı zaman fizik muayenenin duyarlıık ve özgüllüğünün yüksek olmasına rağmen istatistiksel olarak anlamlı bir belirleyiciliğinin olmadığı görüldü $(p<0.00 I)$.

TARTIŞMA: Ultrasonografinin karın içi sıvı saptanmasında gerçekten güvenilir bir yöntem olduğu anlaşılmakla birlikte organ yaralanmalarının saptanmasında US ve fizik muayenenin güvenilir olmadığı görülmektedir.

Anahtar sözcükler: Batın; fizik muayene; tomografi; travma; ultrasonografi.

Ulus Travma Acil Cerrahi Derg 2019;25(4):369-377 doi: 10.5505/tjtes.2018.88288 